Original Research Paper

\title{
$\beta$-carotene Supplementation Increases Progesterone Concentration and Glutathione Peroxidase Activity Following Alternative Progesterone Primed Oestrous Synchronization Protocol in Goats
}

\author{
${ }^{1,2}$ Dominic Lado Marino Gore and ${ }^{3 *}$ Khoboso Christina Lehloenya \\ ${ }^{1}$ Department of Animal and Wildlife Sciences, University of Pretoria, Hatfield, 0002, South Africa \\ ${ }^{2}$ Department of Animal Production, University of Juba, P.O. Box 82 Juba, South Sudan \\ ${ }^{3}$ Department of Agriculture, University of Zululand, Private Bag X1001, KwaDlangezwa 3886, South Africa
}

\author{
Article history \\ Received: 19-05-2020 \\ Revised: 27-06-2020 \\ Accepted: 07-08-2020 \\ Corresponding Author: \\ Khoboso Christina Lehloenya, \\ Department of Agriculture, \\ University of Zululand, Private \\ Bag X1001, KwaDlangezwa \\ 3886, South Africa \\ Email: LehloenyaK@unizulu.ac.za \\ khoboso.lehloenya@gmail.com
}

\section{Introduction}

Nutrition affects all aspects of reproductive events from gametogenesis to puberty in both males and females (Scaramuzzi et al., 2006). In females, the most prominent effect is around mating period influencing the wave-like pattern of follicle development, ovulation rate, embryo survival and twining rate (Viñoles Gil, 2003). Short-term supplementation with maize and lupin before ovulation was reported to increase ovulation rate (Nottle et al., 1990; Nogueira et al., 2017). The period post ovulation is also very crucial for

\begin{abstract}
The present study evaluated the effect of $\beta$-carotene supplementation and oestrous synchronization protocol on ovarian activity and fertility of Saanen does during the breeding season. The supplemented group received $100 \mathrm{mg} \beta$-carotene during the breeding and all does were synchronised with Controlled Internal Drug Release dispenser (CIDR) and injected with cloprostenol at CIDR withdrawal. One group of does were injected with $300 \mathrm{IU}$ of eCG, while in another group bucks wearing aprons were introduced at CIDR withdrawal. Does were artificially inseminated twice (48 and $60 \mathrm{~h}$ ) with fresh undiluted semen. The onset and duration of estrus, progesterone, oestrdiol-17 $\beta$ and glutathione peroxidase activity, protous response and conception rate were analysed. Synchronization and oestradiol-17 $\beta$ concentration. The male presence group had significantly higher conception rate $(97 \%)$ than the eCG (72\%) group. $\beta$ carotene supplemented group had higher progesterone concentration and glutathione peroxidase activity. Supplemental $\beta$-carotene during the breeding period therefore, could play an important role on establishment of pregnancy due to high progesterone concentration and glutathione peroxidase activity. Inclusion of male effect in progesterone based oestrous synchronization protocol improves conception rate. Therefore, male effect can be used as an alternative to equine chorionic gonadotropin in progesterone based oestrous synchronization protocols especially, where drugs for oestrous synchronization are not affordable.
\end{abstract}

Keywords: Artificial Insemination, Buck Effect, eCG, Glutathione Peroxidase Activity, Oestradiol-17 $\beta$, Progesterone survival of embryos in farm animals. Many reports have associated the concentration of systemic progesterone with early embryo loss and that progesterone supplementation in cows, particularly those with low progesterone concentration, can reduce this loss (Morris and Diskin, 2008). Most embryonic mortality occurs between day 8 and 16 in cattle (Diskin and Sreenan, 1980) and during the first four weeks of pregnancy in sheep (Petrović et al., 2012).

$\beta$-carotene is a primary precursor for vitamin $\mathrm{A}$, but also has been noted to play specific roles on some aspects of ovarian activity such as being an antioxidant 
for quenching singlet oxygen and scavenging peroxyl radicals (Sies and Stahl, 1995) which are harmful during steroidogenesis (Arellano-Rodriguez et al., 2009; Meza-Herrera et al., 2013a; 2013b). As an antioxidant, $\beta$-carotene supplementation has been reported to decrease oxidative stress (Otomaru et al., 2018) and increase total protein, glucose and cholesterol, while decreases urea concentrations in the female goat (Meza-Herrera et al., 2017). $\beta$-carotene has also been implicated in the luteal cells function for the synthesis of progesterone in goats (Arellano-Rodriguez et al., 2009). Additionally, high concentration of $\beta$-carotene in corpora lutea is reported to promote ovarian steroidogenesis and increases plasma progesterone concentration in goats and cats (Weng et al., 2000; Arellano-Rodriguez et al., 2009; Meza-Herrera et al., 2013a). Studies have reported the positive effect of $\beta$-carotene on the response to oestrus, improved ovulation rate and conception rate in cattle and goats (Aréchiga et al., 1998; de Ondarza et al., 2009; Arellano-Rodriguez et al., 2007; 2009; Meza-Herrera et al., 2013b; López-Flores et al., 2018). However, other studies have refuted the positive effect of $\beta$-carotene on ovarian activity and fertility. For example, plasma progesterone concentration, incidence and duration of oestrus and first conception rate were not influenced by supplemental $\beta$-carotene in cattle (Wang et al., 1988b). In addition, there were no effects of $\beta$-carotene supplementation observed on progesterone production, ovarian activity, cervix and uterine diameters in cows (Kaewlamun, 2010). Due to the conflicting results and limited studies in goats concerning $\beta$-carotene effect on reproduction, more studies are necessary in order to ascertain its effects on reproduction. Concerning few studies in goats, $\beta$-carotene supplementation improved follicular development, ovulation rate and progesterone production (Arellano-Rodriguez et al., 2009; Meza-Herrera et al., 2013b; López-Flores et al., 2018).

Progesterone or its analogues in combination with eCG as a co-treatment has been widely used for oestrous synchronization in goats. However, repeated eCG treatments over a period of time are followed by decreased fertility in inseminated goats (Baril et al., 1996; Roy et al., 1999). The decreased fertility is attributed to the presence of circulating anti-eCG antibodies in the plasma of goats treated with eCG. As a result, there is a need to find alternative cotreatments. In this study we evaluated the possibility of replacing eCG with the male effect in a synchronization protocol, as the male effect induce similar attributes to eCG such as the increase of both FSH and LH and triggering ovulation (Ungerfeld, 2003).

Given the above positive attributes of $\beta$-carotene and male effect, we hypothesized that supplemental $\beta$ carotene and male effect would positively influence the response to oestrus and fertility in goats. Therefore, the aim of this study was to evaluate the effect of short-term $\beta$-carotene supplementation around the breeding period on ovarian activity and fertility of Saanen goats following synchronised oestrus using male effect and eCG progesterone based protocol.

\section{Materials and methods}

\section{Ethical Approval}

This study was approved by the animal ethics committee of the University of Pretoria (Project no.EC108-14).

\section{Experimental Site}

The study was undertaken at the experimental farm of the University of Pretoria, South Africa. The farm lies between latitude $25^{\circ} 44^{\prime} 30^{\prime \prime} \mathrm{S}$ and longitude $28^{\circ} 15^{\prime} 30^{\prime \prime}$ $\mathrm{E}$, with an elevation of 1360 meters above sea level (Van Niekerk et al., 2009).

\section{Experimental Animals and Management System}

Sixty (60) Saanen does of age between 1-6 years were used for this study. The goats were managed under intensive system and fed with a Total Mixed Ration (TMR), the ingredients are presented in Table 1. Water access was ad libitum throughout the duration of the study.

\section{Experimental Design and Treatments}

The does were allocated into two groups on their weight and parity; Group 1: $\beta$-carotene supplemented (n $=30)$ and Group 2: Non-supplemented $(\mathrm{n}=30)$ group. Further, the experimental groups were sub-divided into two oestrous synchronization protocols; (1) Progesterone $(\mathrm{CIDR})+$ Prostaglandin $(\mathrm{PGF} 2 \alpha)+$ equine chorionic gonadotropin (eCG) and (2) Progesterone (CIDR) + Prostaglandin (PGF2 $\alpha)+$ Male effect (ME).

\section{$\beta$-Carotene Supplementation}

For the $\beta$-carotene groups, goats were supplemented with $\beta$-carotene (100 mg/goat/day) (Pennville Pty Ltd, Gauteng, South Africa) orally according to the company instructions, for a period of 58 days starting 28 days before oestrous synchronization and 17 days post artificial insemination (AI). The control group received water as placebo with similar quantities as in the treatment group.

Table 1: Feed ingredients for the total mixed ration

\begin{tabular}{lcl}
\hline Ingredients & Dry matter \% & Quantity in $\mathrm{kg} / \mathrm{animal}$ \\
\hline Lucerne hay & 43.81 & 1.600 \\
Eragrostis curvula hay & 24.10 & 0.900 \\
Maize meal & 16.06 & 0.600 \\
Molasses & 9.05 & 0.350 \\
Protein concentrate & 6.98 & 0.250 \\
Total & 100.00 & 3.700 \\
\hline
\end{tabular}




\section{Oestrus Synchronization Protocols}

The bucks were kept away from females for a duration of one month before the onset of the study. Thereafter, all the does were intravaginally inserted with Controlled Internal Drug Release dispenser (CIDR) (Pfizer, New Zealand) containing $0.3 \mathrm{~g}$ progesterone and the CIDRs were removed after a duration of 11 days. All does were injected with $150 \mu \mathrm{g}$ cloprostenol (Intervet Schering-Plough Animal Health, South Africa) at CIDR withdrawal. In addition, at CIDR withdrawal does were divided into two groups: In the first one does were injected with $300 \mathrm{IU}(2.5 \mathrm{~mL})$ of eCG (Intervet Schering-Plough Animal Health, South Africa) and in the second does were mixed with two bucks fitted with aprons in another group and left with the does for $72 \mathrm{~h}$.

\section{Semen Collection and Artificial Insemination (AI)}

\section{Semen Collection}

Semen from bucks was harvested using an electro ejaculator (Ramsem, South Africa) following procedures described by (Sundararaman et al., 2007). The rectal probe was inserted in the rectum and following the insertion of the rectal probe, buck was stimulated through massaging and the machine button was pressed to generate a voltage of 3-5 volts and paused for 4-5 sec and again brought back to 0 . It is replicated until a buck discharged semen. The semen ejaculate volume was recorded and semen mass motility was evaluated as described by (Dogan et al., 2005). Ten (10) $\mu \mathrm{L}$ of semen harvested from each buck was placed on a glass slide and evaluated using a microscope (Olympus Cx21). Only semen ejaculate scoring motility of 3 and beyond were selected and used for insemination of the does.

\section{Artificial Insemination}

Does were artificially inseminated using the method outlined by (Steyn, 2005). Briefly, each doe was inseminated with $0.2 \mathrm{~mL}$ fresh undiluted semen with a concentration between $300-800 \times 10^{6}$ sperm cells/ml as outlined by (Lehloenya et al., 2005) with modifications. All does were cervically inseminated, at fixed times of 48 and $60 \mathrm{~h}$ following CIDR withdrawal (Motlomelo et al., 2002).

\section{Data Collection and Analysis}

\section{Blood Sampling for Hormonal and Enzyme Assay}

Blood samples from 5 goats in each sub-group were collected. The blood samples were collected at CIDR insertion, $8 \mathrm{~h}$ and $48 \mathrm{~h}$ after CIDR removal as well as 12 days post AI. Immediately, following collection, the blood samples were centrifuged at $3000 \times \mathrm{g}$ for $20 \mathrm{~min}$. The blood plasma recovered was then stored at $-20^{\circ} \mathrm{C}$ until analysed for progesterone, oestradiol-17 $\beta$ and glutathione peroxidase activity.

\section{Analysis of Hormones and Enzyme Activity}

The analyses were done using FC Microplate Photometer Thermo Scientific Multiskan®. The plasma progesterone and oestradiol-17 $\beta$ concentrations were analysed using progesterone ELISA DE1561 kit (Demeditec-Germany) with intra and inter assay variability of 5.4-6.86 and 4.34-9.96 and oestradiol-17 $\beta$ ELISA DE2693 kit (Demeditec-Germany) with 2.716.81 and 6.72-9.39, respectively, while glutathione peroxidase activity was analysed using glutathione peroxidase assay kit (ab102530-Abcam) with minimum detection sensitivity of $0.5 \mathrm{mU} / \mathrm{mL}$.

\section{Monitoring the Onset and Duration of Oestrus}

The onset and duration of oestrous were monitored following CIDR removal using two aproned buck for a duration of $72 \mathrm{~h}$ at $8 \mathrm{~h}$ interval (06:00, 14:00 and 22:00 h for $1 \mathrm{~h}$ period) according to (Lehloenya et al., 2005; Ramukhithi et al., 2012). A doe considered to be on oestrus when accepted mounting by the buck and out of oestrus when it did not allow to be mounted.

\section{Ultrasonographic Evaluation of Pregnancy}

Pregnancy detection was done 35 days following artificial insemination using real-time B-mode ultrasound scanner (Aloka, 500 SSD, Japan) fitted with a transrectal 7.5-MHz linear array probe (UST-660-7.5 model).

\section{Statistical Analysis}

The onset and duration of oestrus, progesterone, oestrdiol-17 $\beta$ and glutathione peroxidase activity were analysed using Analysis of Variance (ANOVA) and the oestrous response and conception rate were analysed using Chi-square test procedures of (SAS, 2014). Significance level was set at $\mathrm{P}<0.05$.

\section{Results}

One goat was removed from the experiment due to reproductive tract abnormalities. The response to oestrus, onset and duration of oestrus and conception rate were not significantly different $(\mathrm{P}>0.05)$ between the supplemented and control group (Table 2).

Additionally, most does expressed oestrus signs 32 $\mathrm{h}$ following CIDR removal in both groups (Fig. 4). Supplemental $\beta$-carotene however, increased significantly $(\mathrm{P}<0.05)$ the progesterone concentration at day 12 following Artificial Insemination (AI) (Fig. 1). Oestradiol-17 $\beta$ concentrations were not affected by supplemental $\beta$-carotene throughout the period of measurement but result not presented. The concentration of oestradiol $-17 \beta$ at CIDR withdrawal, 8 $\mathrm{h}$ after CIDR withdrawal, $48 \mathrm{~h}$ after CIDR withdrawal and 12 days after CIDR withdrawal for $\beta$-carotene supplemented group were $1.39 \pm 0.24, \quad 3.90 \pm 0.13$, 
$9.12 \pm 0.42$ and $0.69 \pm 0.16$ and for control group were $1.47 \pm 0.24, \quad 3.85 \pm 0.13, \quad 8.70 \pm 0.42$ and $0.75 \pm 0.16$, respectively. The glutathione peroxidase activity was significantly $(\mathrm{P}<0.05)$ higher in $\beta$-carotene supplemented goats at CIDR insertion, $8 \mathrm{~h}$ and $48 \mathrm{~h}$ following CIDR withdrawal and at day 12 following AI (Fig. 2).

Table 2: Effect of $\beta$-carotene supplementation and synchronization protocol on estrous response and conception rate of Saanen does

\begin{tabular}{|c|c|c|c|c|c|}
\hline & $\begin{array}{l}\text { No of does } \\
\text { responded }\end{array}$ & $\begin{array}{l}\text { Oestrous } \\
\text { response }(\%)\end{array}$ & $\begin{array}{l}\text { Onset of } \\
\text { oestrus (h) }\end{array}$ & $\begin{array}{l}\text { Duration of } \\
\text { oestrus (h) }\end{array}$ & $\begin{array}{l}\text { Conception } \\
\text { rate }(\%)\end{array}$ \\
\hline \multicolumn{6}{|l|}{ Supplementation } \\
\hline$\beta$-carotene supplemented & $28 / 29$ & 96.550 & $28.41 \pm 0.91$ & $30.06 \pm 0.81$ & 86.670 \\
\hline Control & $30 / 30$ & 100.000 & $26.00 \pm 0.91$ & $30.04 \pm 0.81$ & 83.330 \\
\hline P-value & & 0.980 & 0.061 & 1.00 & 0.978 \\
\hline \multicolumn{6}{|l|}{ Synchronization } \\
\hline eCG & $29 / 30$ & 97.000 & $28.29 \pm 0.94$ & $29.43 \pm 0.83$ & 72.000 \\
\hline $\mathrm{Me}$ & $30 / 30$ & 100.000 & $26.13 \pm 0.90$ & $30.67 \pm 0.80$ & 97.000 \\
\hline $\mathrm{P}$-value & & 0.980 & 0.104 & 0.287 & 0.028 \\
\hline \multicolumn{6}{|l|}{ Interaction } \\
\hline$\beta$-carotene supplemented $\times$ eCG & $13 / 14$ & 92.860 & $28.00 \pm 1.32$ & $29.14 \pm 1.17$ & 71.430 \\
\hline$\beta$-carotene supplemented $\times \mathrm{Me}$ & $15 / 15$ & 100.000 & $24.00 \pm 1.32$ & $30.93 \pm 1.13$ & 93.330 \\
\hline Control $\times \mathrm{eCG}$ & $15 / 15$ & 100.000 & $28.57 \pm 1.32$ & $29.71 \pm 1.17$ & 73.330 \\
\hline ControlxMe & $15 / 15$ & 100.000 & $28.27 \pm 1.28$ & $30.40 \pm 1.13$ & 100.000 \\
\hline P-value & & 0.980 & 0.161 & 0.633 & 0.759 \\
\hline
\end{tabular}

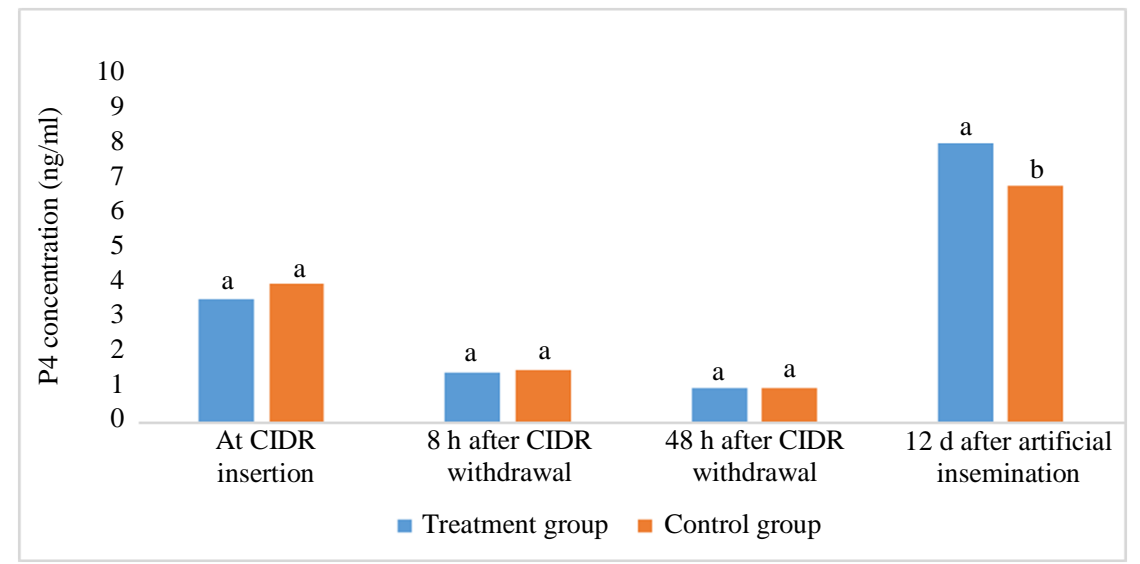

Fig. 1: Effect of supplemental $\beta$-carotene on the progesterone (P4) concentration of Saanen goats. Bars with different letters are significantly different $\left(\mathrm{P}<0.05 ;{ }^{\mathrm{a}, \mathrm{b}}\right.$ significant within a time $)$

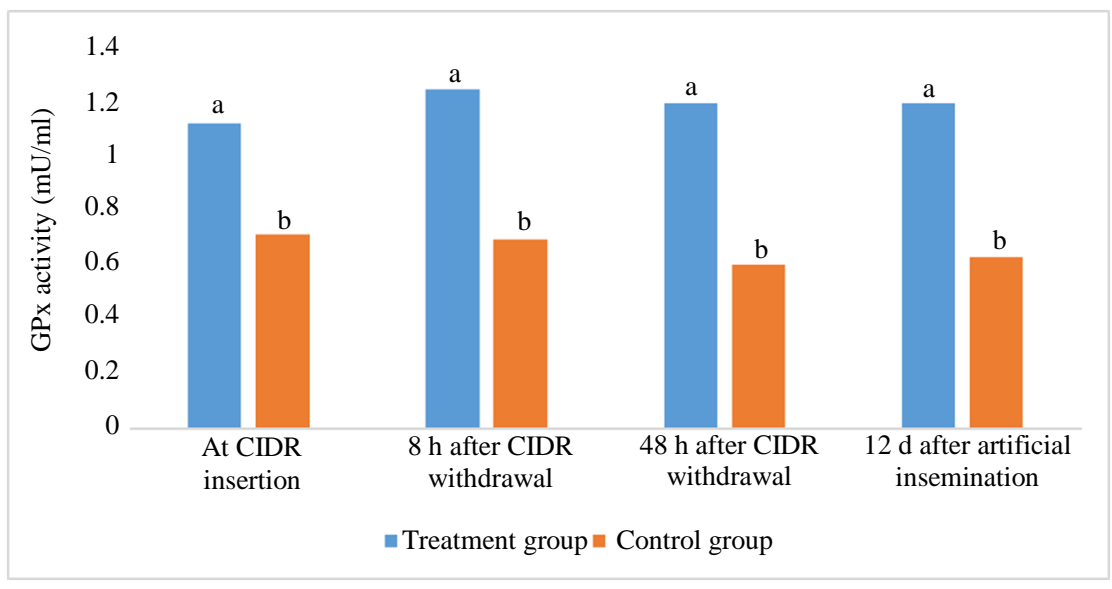

Fig. 2: Effect of supplemental $\beta$-carotene on Glutathione Peroxidase activity (GPx) of Saanen goats. Bars with different letters are significantly different $\left(\mathrm{P}<0.05{ }^{\text {a,b }}\right.$ significant within a time $)$ 


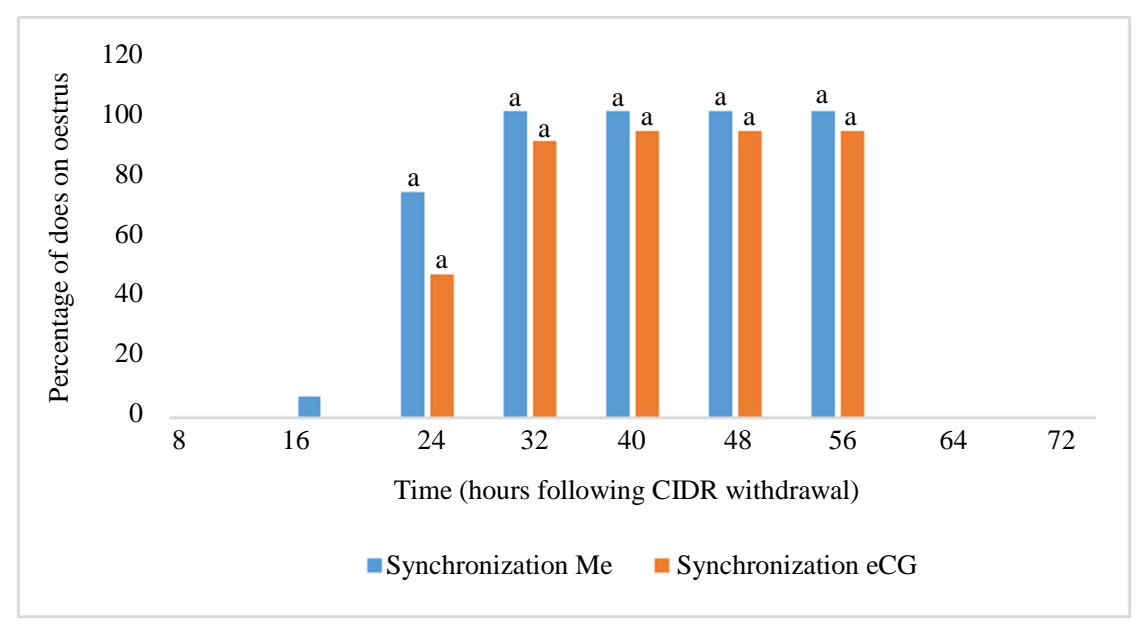

Fig. 3: Effect of synchronization protocols (Male effect (Me) and equine chorionic gonadotropin (eCG)) on response to oestrus in Saanen goats. $(\mathrm{P}<0.05 ;$ a,a not significant within a time $)$

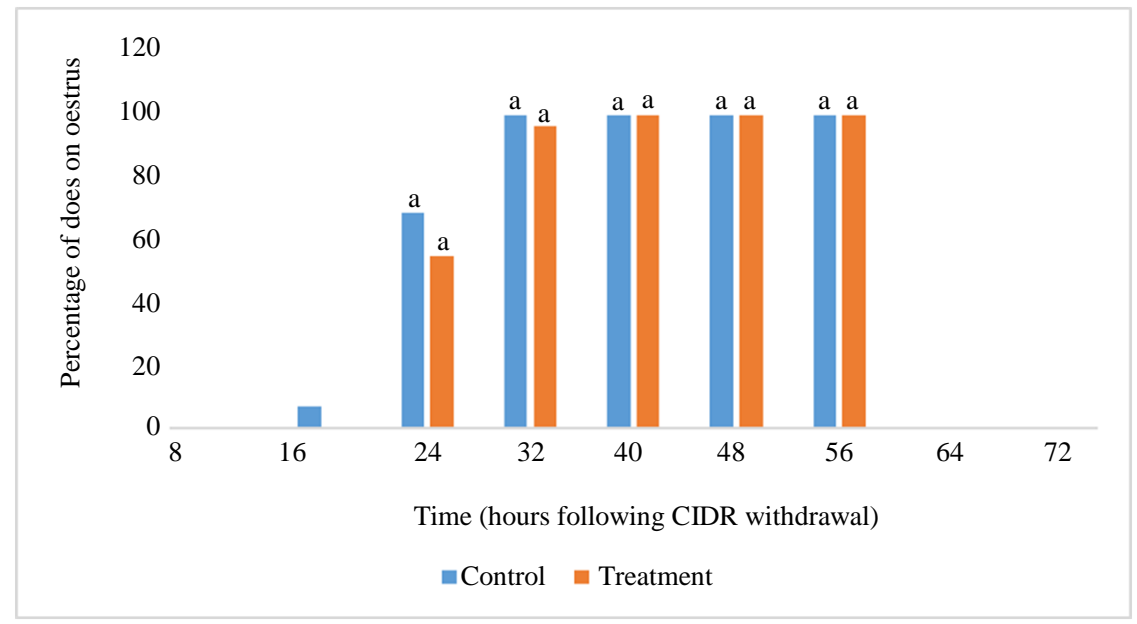

Fig. 4: Effect of $\beta$-carotene supplementation on response to oestrus in Saanen goats. $\left(\mathrm{P}<0.05 ;{ }^{\mathrm{a}, \mathrm{a}}\right.$ not significant within a time)

On oestrous synchronization protocols, there was no significant difference $(\mathrm{P}>0.05)$ (Table 2$)$ between the eCG and male effect group on the response to oestrus, onset and duration of oestrus. However, in male effect group, does expressed oestrus earlier than the eCG group and majority of does expressed oestrus $32 \mathrm{~h}$ following CIDR removal as shown in (Fig. 3). The oestrous synchronization protocol had a significant effect $(\mathrm{P}<0.05)$ on conception rate (Table 2). The male effect group had significantly $(\mathrm{P}<0.05)$ higher conception rate than the eCG group. The interactions were tested but all not significant.

\section{Discussion}

The current study has partly confirmed the hypothesis that $\beta$-carotene supplementation and male effect based oestrous synchronization protocol would positively influence hormonal concentration, response to oestrus and fertility in goats. The study found that supplemental $\beta$ carotene increased progesterone concentration and glutathione peroxidase activity, in goats. Additionally, the study revealed that male effect based oestrous synchronization significantly improved conception rate in goats. Other parameters measured in the current study however, were not affected by $\beta$-carotene supplementation and male effect based oestrous synchronization protocol.

The high concentration of progesterone following supplemental $\beta$-carotene in the current study agrees with findings of other researchers (Weng et al., 2000; Arellano-Rodriguez et al., 2009). This increase in concentration of progesterone on day 12 following artificial insemination could be attributed to implication of $\beta$-carotene in progesterone synthesis through the steroidogenic process. $\beta$-carotene concentration increases in a dose dependent manner in Corpus Luteum (CL) (Weng et al., 2000) and this could play role in 
progesterone synthesis and prevention of lipid peroxidation (Young et al., 1995; Arikan and Rodway, 2000; Weng et al., 2000). Lack of $\beta$-carotene effect on progesterone concentration 8 and $48 \mathrm{~h}$ following CIDR removal could be attributed to the fact that there was no active CL and as such no synthesis of progesterone was taking place.

The high GPx activity following supplemental $\beta$ carotene in the current study agrees with other researchers (Kamİloğlu et al., 2005) who observed improved antioxidant activity of GPx in sheep before breeding and during pregnancy period. This improvement in GPx activity is attributed to increase in protection from oxygen free radicals during oxidative stress (Festila et al., 2012). However, supplemental $\beta$-carotene in the current study did not improve concentration of oestradiol-17 $\beta$ and this concurs with a study (Weng et al., 2000).

The current study did not influence conception rate following $\beta$-carotene supplementation and this is in agreement with some studies in cows (Bindas et al., 1984; Wang et al., 1988a; 1988b). There are however, other studies that disagreed with the current findings who reported improved fertility rate following $\beta$ carotene supplementation in cows (Aréchiga et al., 1998; De Ondarza et al., 2009). These discrepancies could be attributed to the species differences, goats are efficient converters of $\beta$-carotene in their intestinal mucosa compared to cattle (McDowell, 2000). Due to this reason, cattle have more circulating $\beta$-carotene concentration in their body tissues than in goats (Yang et al., 1992) and thus the improved fertility in cattle could be attributed to high $\beta$-carotene concentration which could influence the ovarian activities positively.

Oestrous synchronization protocol did not significantly influence oestrus response, onset and duration of induced oestrus in the current study. This could be attributed to the fact that both eCG and male effect of possessed similar attributes of inducing ovulation (Leboeuf et al., 1998). In line with the findings of the current study, supplemental $\beta$-carotene did not affect response to oestrus and onset of oestrus in cattle (Wang et al., 1987; Aréchiga et al., 1998). In disagreement with the current study, supplemental $\beta$ carotene reduced the incidence of onset of oestrus (Wang et al., 1982). The current study agrees with the findings of previous studies who reported no effect of supplemental $\beta$-carotene on the duration of oestrus (Wang et al., 1982; 1988b). There was however, a positive effect of oestrous synchronization protocol on conception rate.

Interestingly, the male effect based protocol had significantly high conception rate compared to the eCG based protocol. The high conception rate in male effect group could be attributed to the following: Firstly, the onset of oestrus was slightly earlier in the male effect group and consequently the time of artificial insemination was more appropriate for male effect group than eCG group. Secondly, the physical presence of male is associated with lower stress in female animals. Male effect is linked with the stable secretion pattern of cortisol, whereas vomerolectomized goats experienced increased concentration of cortisol due to failure in sensing the male presence (Jansen van Vuuren, 2015). The known link of stress (based on cortisol concentration) is that cortisol releasing hormone is directly affected by a similar pathway that stimulates the release of gonadotropin releasing hormone and its inhibition is a secondary effect to luteinizing hormone and estradiol (Swenson and Reece, 1993). This positive role of male existence on conception rate may possibly encourage the use of the male effect when synchronising oestrus in progesterone primed goats to avoid the intensive application of eCG. The eCG has been associated with reduced fertility in goats when used repeatedly (Baril et al., 1996; Roy et al., 1999). Therefore, male effect offers an alternative to eCG in progesterone based synchronization protocols during the breeding season. The option would not only reduce the quantity of hormones used in a synchronization protocol but also maintain fertility, since synchronization of oestrus using eCG is implicated in reducing fertility over time, attributed to the presence of circulating anti-eCG antibodies in the plasma of goats treated with eCG (Baril et al., 1996; Roy et al., 1999).

\section{Conclusion}

Supplemental $\beta$-carotene did not influence ovarian activity and conception rate. $\beta$-carotene supplementation however, improved plasma progesterone concentration and GPx activity. The male effect based oestrous synchronization protocol improved conception rate compared to eCG based protocol. Supplemental $\beta$-carotene during the breeding period therefore, could play an important role on establishment of pregnancy due to the high progesterone concentration and glutathione peroxidase activity. Inclusion of male effect in progesterone based oestrous synchronization protocol improves conception rate. Therefore, male effect can be used as an alternative to equine chorionic gonadotropin in progesterone based oestrous synchronization protocols especially, where drugs for oestrous synchronization are not affordable.

\section{Acknowledgment}

The authors acknowledge the Office of International Research, Education and Development (OIRED) through Rebuilding Higher Education in Agriculture (RHEA) project implemented by Virginia Tech and Borlaug Higher Education for Agricultural Research and Development (BHEARD) project implemented by 
Michigan State University under the umbrella of USAID for providing financial assistance for this study as well as the University of Pretoria for providing the experimental animals.

\section{Funding Information}

This material is based upon work supported by the United States Agency for International Development, as part of the Feed the Future Initiative, under the CGIAR Fund, award number BFS-G-11-00002 and the predecessor fund the Food Security and Crisis Mitigation II grant, award number EEM-G-00-04-00013.

\section{Author's Contributions}

Dominic Lado Marino Gore: Contributed on the original ideas of the manuscript, data collection, analysis and interpretation and manuscript write up.

Khoboso Christina Lehloenya: Contributed on the original ideas and preparation of the manuscript.

\section{Ethics}

The authors confirm that the manuscript has not been published or not under consideration elsewhere for publication in another journal. This work is part of the master's dissertation of the first author and the second author was the supervisor.

\section{References}

Aréchiga, C. F., Staples, C. R., McDowell, L. R., \& Hansen, P. J. (1998). Effects of Timed Insemination and Supplemental $\beta$-Carotene on Reproduction and Milk Yield of Dairy Cows Under Heat Stress1. Journal of Dairy Science, 81(2), 390-402.

Arellano-Rodriguez, G., Meza-Herrera, C. A., Rodriguez-Martinez, R., Velazquez-Mendez, G., Mellado, M., Salinas, H., ... \& Sanchez, F. (2007). Short-term betacarotene supplementation positively affects ovarian follicular development and ovulation rate in goats. Journal of Applied Animal Research, 32(2), 177-180.

Arellano-Rodriguez, G., Meza-Herrera, C. A., Rodriguez-Martinez, R., Dionisio-Tapia, R., Hallford, D. M., Mellado, M., \& Gonzalez-Bulnes, A. (2009). Short-term intake of $\beta$-carotene-supplemented diets enhances ovarian function and progesterone synthesis in goats. Journal of Animal Physiology and Animal Nutrition, 93(6), 710-715.

Arikan, Ş., \& Rodway, R. G. (2000). Effects of high density lipoprotein containing high or low $\beta$ carotene concentrations on progesterone production and $\beta$-carotene uptake and depletion by bovine luteal cells. Animal Reproduction Science, 62(4), 253-263.
Baril, G., Remy, B., Leboeuf, B., Beckers, J. F., \& Saumande, J. (1996). Synchronization of estrus in goats: the relationship between eCG binding in plasma, time of occurrence of estrus and fertility following artificial insemination. Theriogenology, 45(8), 1553-1559.

Bindas, E. M., Gwazdauskas, F. C., Aiello, R. J., Herbein, J. H., McGilliard, M. L., \& Polan, C. E. (1984). Reproductive and metabolic characteristics of dairy cattle supplemented with $\beta$-carotene. Journal of Dairy Science, 67(6), 1249-1255.

De Ondarza, M. B., Wilson, J. W., \& Engstrom, M. (2009). Case study: Effect of supplemental $\beta$ carotene on yield of milk and milk components and on reproduction of dairy cows. The Professional Animal Scientist, 25(4), 510-516.

Diskin, M. G., \& Sreenan, J. M. (1980). Fertilization and embryonic mortality rates in beef heifers after artificial insemination. Reproduction, 59(2), 463-468.

Dogan, I., Nur, Z., Gunay, U., Sagirkaya, H., Soylu, M. K., \& Sonmez, C. (2005). Estrous synchronization during the natural breeding season in Anatolian black does. Vet Med-Czech, 50(1), 33-38.

Festila, I., Miresan, V., Raducu, C., Cocan, D., Constantinescu, R., \& Coroian, A. (2012). Evaluation of oxidative stress in dairy cows through antioxidant enzymes glutathione peroxidase (GPX) and superoxide dismutase (SOD). Bulletin of University of Agricultural Sciences and Veterinary Medicine Cluj-Napoca. Animal Science and Biotechnologies, 69(1-2).

Viñoles Gil, C. (2003). Effect of nutrition of follicle development and ovulation rate in the ewe: doctoral thesis.

Jansen van Vuuren, J. (2015). The role of the Vomeronasal Organ in the endocrine response of does in oestrus (Doctoral dissertation, University of Pretoria).

Kaewlamun, W. (2010). Effects of heat stress and $\beta$ carotene supplementation on postpartum reproductive performance in dairy cows (Doctoral dissertation, Chulalongkorn University).

Kamİloğlu, N. N., Beytut, E., Gürbulak, K., \& Öğün, M. (2005). Effects of Vitamin A and/beta-Carotene Injection on Levels of Vitamin E and on Glutathione Peroxidase Activity in Pregnant Tuj Sheep. Turkish Journal of Veterinary and Animal Sciences, 29(4), 1033-1038.

Leboeuf, B., Manfredi, E., Boue, P., Piacère, A., Brice, G., Baril, G., ... \& Terqui, M. (1998). Artificial insemination of dairy goats in France. Livestock Production Science, 55(3), 193-203.

Lehloenya, K. C., Greyling, J. P. C., \& Schwalbach, L. M. J. (2005). Reproductive performance of South African indigenous goats following oestrous synchronisation and AI. Small Ruminant Research, 57(2-3), 115-120 
López-Flores, N. M., Meza-Herrera, C. A., GalánSoldevilla, C., Bautista-Rodriguez, D. A., VelizDeras, F. G., Arellano-Rodriguez, G., ... \& MaciasCruz, U. (2018). The key role of targeted betacarotene supplementation on endocrine and reproductive outcomes in goats: Follicular development, ovulation rate and the GH-IGF-1 axis. Small Ruminant Research, 163, 29-33.

McDowell, L. R. (2000). Vitamins in Animal and Human Nutrition. Iowa State University Press, Ames, Iowa, USA.

Meza-Herrera, C. A., Vargas-Beltran, F., Tena-Sempere, M., González-Bulnes, A., Macias-Cruz, U., \& VelizDeras, F. G. (2013a). Short-term beta-carotenesupplementation positively affects ovarian activity and serum insulin concentrations in a goat model. Journal of Endocrinological Investigation, 36(3), 185-189.

Meza-Herrera, C. A., Vargas-Beltran, F., VergaraHernandez, H. P., Macias-Cruz, U., Avendaño-Reyes, L., Rodriguez-Martinez, R., ... \& Veliz-Deras, F. G. (2013b). Betacarotene supplementation increases ovulation rate without an increment in LH secretion in cyclic goats. Reproductive Biology, 13(1), 51-57.

Meza-Herrera, C. A., Pacheco-Alvarez, P., Castro, O. E., Macias-Cruz, U., Avendaño-Reyes, L., Mellado, M., ... \& Arellano-Rodriguez, G. (2017). Beta-carotene supplementation positively affects selected blood metabolites across time around the onset of puberty in goats. Czech Journal of Animal Science, 62(1), 22-31.

Morris, D., \& Diskin, M. (2008). Effect of progesterone on embryo survival. Animal: an international journal of animal bioscience, 2(8), 1112.

Motlomelo, K. C., Greyling, J. P. C., \& Schwalbach, L. M. J. (2002). Synchronisation of oestrus in goats: the use of different progestagen treatments. Small Ruminant Research, 45(1), 45-49.

Nogueira, D. M., Eshtaeba, A., Cavalieri, J., Fitzpatrick, L. A., Gummow, B., Blache, D., \& Parker, A. J. (2017). Short-term supplementation with maize increases ovulation rate in goats when dietary metabolizable energy provides requirements for both maintenance and 1.5 times maintenance. Theriogenology, 89, 97-105.

Nottle, M. B., Seamark, R. F., \& Setchell, B. P. (1990). Feeding lupin grain for six days prior to a cloprostenolinduced luteolysis can increase ovulation rate in sheep irrespective of when in the oestrous cycle supplementation commences. Reproduction, Fertility and Development, 2(2), 189-192.

Otomaru, K., Ogawa, R., Oishi, S., Iwamoto, Y., Hong, H., Nagai, K., ... \& Kaneshige, T. (2018). Effect of Beta-Carotene Supplementation on the Serum Oxidative Stress Biomarker and Antibody Titer against Live Bovine Respiratory Syncytial Virus Vaccination in Japanese Black Calves. Veterinary sciences, 5(4), 102.
Petrović, M. P., Caro Petrović, V., Ružić-Muslić, D. Maksimović, N., Ilić, Z. Z., Milošević, B., \& Stojković, J. (2012). Some important factors affecting fertility in sheep. Biotechnology in Animal Husbandry, 28(3), 517-528.

Ramukhithi, F. V., Nedambale, T. L., Sutherland, B., Greyling, J. P. C., \& Lehloenya, K. C. (2012). Oestrous synchronisation and pregnancy rate following artificial insemination (AI) in South African indigenous goats. Journal of Applied Animal Research, 40(4), 292-296.

Roy, F., Maurel, M. C., Combes, B., Vaiman, D., Cribiu, E. P., Lantier, I., ... \& Guillou, F. (1999). The negative effect of repeated equine chorionic gonadotropin treatment on subsequent fertility in Alpine goats is due to a humoral immune response involving the major histocompatibility complex. Biology of reproduction, 60(4), 805-813.

SAS, (2014). Version 9.4. Inc. Cary Institute, North Carolina, USA.

Scaramuzzi, R. J., Campbell, B. K., Downing, J. A., Kendall, N. R., Khalid, M., Muñoz-Gutiérrez, M., \& Somchit, A. (2006). A review of the effects of supplementary nutrition in the ewe on the concentrations of reproductive and metabolic hormones and the mechanisms that regulate folliculogenesis and ovulation rate. Reproduction Nutrition Development, 46(4), 339-354.

Sies, H., \& Stahl, W. (1995). Vitamins E and C, betacarotene and other carotenoids as antioxidants. The American journal of clinical nutrition, 62(6), $1315 \mathrm{~S}-1321 \mathrm{~S}$.

Steyn, J. J. (2005). Application of Artificial Insemination (AI) on commercial sheep and goat production. Ramsem, South Africa.

Sundararaman, M. N., Kalatharan, J., \& Edwin, M. J. (2007). Attempts to achieve semen collections from incapacitated Boer bucks by electroejaculation. Asian Joumal of Animal and Veterinary Advances, 2, 244-246.

Swenson, M. J., \& Reece, W. O. (1993). Dukes physiology of domestic animals. Comstock Publishing Associates a Division of Cornell University Press, USA.

Ungerfeld, R. (2003). Reproductive responses of anestrous ewes to the introduction of rams (Vol. 163).

Van Niekerk, W. A., Hassen, A., Snyman, L. D., Rethman, N. F., \& Coertze, R. J. (2009). Influence of mineral composition and rumen degradability of Atriplex nummularia (Hatfield Select F1) plants on selection preference of sheep. African Journal of Range \& Forage Science, 26(2), 91-96.

Wang, J. Y., Hafi, C. B., Owen, F. G., \& Larson, L. L. (1987). Effect of beta-carotene supplementation on periparturient health and reproduction of Holstein cows. Animal Reproduction Science, 15(1-2), 139-144. 
Wang, J. Y., Hafi, C. B., \& Larson, L. L. (1988a). Endocrine responses and estrous activity in holstein heifers fed supplemental beta-carotene. Theriogenology, 29(3), 731-742.

Wang, J. Y., Owen, F. G., \& Larson, L. L. (1988b). Effect of beta-carotene supplementation on reproductive performance of lactating Holstein cows. Journal of dairy science, 71(1), 181-186.

Wang, J. Y., Larson, L. L., \& Owen, F. G. (1982). Effect of beta-carotene supplementation on reproductive performance of dairy heifers. Theriogenology, 18(4), 461-473.

Weng, B. C., Chew, B. P., Wong, T. S., Park, J. S., Kim, H. W., \& Lepine, A. J. (2000). $\beta$-carotene uptake and changes in ovarian steroids and uterine proteins during the estrous cycle in the canine. Journal of animal science, 78(5), 1284-1290.
Yang, A., Larsen, T. W., \& Tume, R. K. (1992). Carotenoid and retinol concentrations in serum, adipose tissue and liver and carotenoid transport in sheep, goats and cattle. Australian journal of agricultural research, 43(8), 1809-1817.

Young, F. M., Luderer, W. B., \& Rodgers, R. J. (1995). The antioxidant $\beta$-carotene prevents covalent crosslinking between cholesterol side-chain cleavage cytochrome $\mathrm{P} 450$ and its electron donor, adrenodoxin, in bovine luteal cells. Molecular and cellular endocrinology, 109(1), 113-118. 